\title{
Original Unit or Value of Reported Test Result Indicator
}

National Cancer Institute

\section{Source}

National Cancer Institute. Original Unit or Value of Reported Test Result Indicator. NCI

Thesaurus. Code C70967.

An indicator that can be set or unset in order to signal whether the observation is in the units or values as collected, or it has been converted into standardized units or values. 